\title{
Essential Pathways: An Examination of How Community College Compromise Their Unique Contribution to American Higher Education
}

\author{
Khadijah Zakia Ali-Coleman \\ Morgan State University/ United States
}

\begin{abstract}
Community colleges in the United States have historically held a unique position within the system of higher education because of three characteristics. These characteristics include their doctrine of open access, their consistent affordability in comparison to other higher education options, and courses that are directly applicable to the workforce. However, over the years, contradictions have arisen that compromise the practice of these ideals. Focusing on three policy priorities, this analysis determines how effective community colleges are today in offering students an education that is accessible, applicable to the labor market, and affordable. The concluding points include predictions of what the future of community colleges looks like within the next twenty years.
\end{abstract}

Keywords: community colleges, higher education, policy, educational access, college affordability

Within an often politically polarized society, the American community college continues to represent a legacy of serving learners across socio-economic status, race, gender and pre-college experiences (Great Schools Partnership, 2014; Hutcheson, 2007; Zook, 1947). Community colleges are where almost half of undergraduate college students begin their academic career (Ma \& Baum, 2016). Since 1901, when the first public community college in the United States, Joliet Junior College, opened its doors in Illinois, more than 1200 community colleges have been founded nationally.

This article examines how community colleges contribute to the American system of higher education, and ways that those efforts may be thwarted through 
contradictions that arise in policy, funding, and implementation. Focusing on three policy priorities - remedial education, student debt, and corporate partnerships - this analysis determines how effective community colleges are in offering students an education that is accessible, applicable to the labor market, and affordable. The literature highlights that, while community colleges provide value to the landscape of higher education, there are stark realities that compromise many of the ideals that community colleges represent. The concluding points include predictions of what the future of community colleges might be in the next twenty years.

\section{OPEN ACCESS}

Open access began as the belief that the United States must present accessibility to higher education as a democratic ideal. The Truman Commission on Higher Education report of 1947 asserted that a democratic society must model the behavior, ideals and principles it enforces on the countries it occupies, wages war against and morally rebukes (Zook, 1947). The Truman report is arguably more groundbreaking for its time because it included statements addressing the need to make community college accessible to all people, despite segregation of the races still being federally mandated by law due to the 1896 Plessy v. Ferguson US Supreme Court ruling (Thatthai, 2001). Within this societal context, the Truman Commission on Higher Education report reads as a liberal and progressive doctrine and appears to describe college access as a right for society's most disenfranchised. Thus, open access has become a doctrine of equity, purporting that prospective students of all races, ethnicities, genders, religions and socio-economic statuses will not be discouraged from applying, registering, and attending community colleges (Great Schools Partnership, 2014).

\section{The Doctrine of Open Access}

Today, community colleges enroll more than seven million students (Smith Morest, 2013). While scholars like Shaw et al. (1999) assert that community colleges misrepresent themselves as pathways to social mobility, community colleges continue to attract a student population that is broadly diverse. On average, more than half of community college students are in ethnically diverse states. Smith Morest (2013) discovered that " $60 \%$ of the nation's community college enrollments are concentrated in nine states: California, Texas, Illinois, New York, Florida, Michigan, North Carolina, Arizona, and Ohio" (p. 321). According to Allen and Turner (1989), California, Texas, New York, and Florida rank highest in both racial/ethnic and socioeconomic diversity. More than $40 \%$ of community college students are People of Color, including people who are native born and those who have emigrated to the United States. In addition, community college students are primarily female and largely low to middle income (Nevarez \& Wood, 2010).

Students are choosing public community colleges over private or for-profit institutions because most states enact policies that ensure open access to public community colleges (Ma \& Baum, 2016). In short, open access can be understood as when community colleges institute services, support systems, or opportunities that 


\section{Higher Education Politics \& Economics}

facilitate enrollment despite a possible lack of students' pre-college preparation (Cohen et al., 2014). Community colleges are multi-functional spaces that students attend for many reasons, including the desire "to transfer to a senior institution, enter the job market, get a better job, or merely learn for one's own purposes" (Cohen et al., 2014, p. 70).

While the doctrine of open access is, arguably, the most distinct characteristic that community colleges covey within the higher education landscape, students' requirements upon enrollment, such as remedial courses based on entrance placement test results, mar the praxis behind open access (Bailey et al., 2015; Maitre, 2014; Mejia et al., 2016).

\section{Remedial Courses Are Barriers to the Doctrine of Open Access}

Currently, most community colleges use placement tests, like Accuplacer, to help determine if a student is capable of taking a college level writing, math, or reading course (Krantz, 2015). Black and Latino students are disproportionately impacted by scores on placement tests; they are more apt to be placed in remedial math courses, beginning at the lowest levels, after taking the test (Maitre, 2014). Some research consistently indicates that remedial courses are not improving student success (Bailey et al., 2015; Boggs \& McPhail, 2016; Maitre, 2014).

Bailey et al. (2015) concluded that if developmental courses were instrumental in increasing students' future academic success, then they would gain skills to perform better academically than those students who barely passed the Accuplacer. Instead, their study indicated that "the cutoff [students] did not have better long-term outcomes than students who went directly into college-level courses" (p.122).

The consequence of being required to take remedial courses impacts persistence and matriculation (Boggs \& McPhail, 2016). Research also suggests that the challenge of passing remedial math courses may discourage students so badly that it impacts their choice of major and career (St. Rose \& Hill, 2013) and they are less likely to graduate over a span of six years or less (Boggs \& McPhail, 2016). To compound the issue, there are no consistent federal or state guidelines to determine whether a student should be mandated to enroll in developmental courses or immediately begin college-level math or English.

In summary, while placement test scores could possibly indicate a student's ability or deficiency in a math level, remedial courses are not serving them well overall in improving math skill and academic success; instead, such measures serve as blockades to immediate access to college-level work, jeopardizing the praxis of open access. A type of educational theater, a charade of sorts, is happening when a student enrolls in a community college: due to a placement test, students are not eligible to take credit-bearing college courses - this is not open access to college. However, there are alternatives that exist now, and more that can be created, to optimize student success while demonstrating the doctrine of open access in a more authentic manner. These alternatives include a redesign of math courses and a normalizing of dual-enrollment to specifically avoid the pitfalls of remediation. I will discuss and give examples of these alternatives later in this article in the section that includes my predictions for the next twenty years. 


\section{AFFORDABILITY}

Affordability is another unique contribution community colleges add to the realm of US higher education because community colleges have always been less expensive when compared to four-year institutions. Baum et al. (2014) found that:

...the difference between average published in-state tuition and fees at public four year institutions and average in-district published tuition and fees at public two year institutions ranges from $\$ 1,927$ in Wyoming and \$1,970 in South Dakota to $\$ 8,568$ in New Jersey and $\$ 9,243$ in Illinois. (p. 18)

While $40 \%$ of students who attend community colleges are less likely to be financial dependents, compared to $64 \%$ of students attending four-year institutions (Ma \& Baum, 2016), financing a college career is still a concern for working-class families whom community colleges more often serve. Historically, community college affordability is rarely examined apart from the doctrine of open access (Berube, 1991; Graham, 2011; Hansen \& Stampen, 1987; Thelin, 2011). The issue of affordability has always been at the forefront of the virtues that community colleges reflect.

\section{Debt's Relationship to Affordability}

Affordability was emphasized when President Barack Obama introduced the America's College Promise (ACP) legislative initiative in 2015 to strengthen pathways to community colleges (Palmadessa, 2017). This legislation promoted the notion of free college while asserting that it was creating avenues of entry that did not exist in previous years for students of low socioeconomic status. Yet, some critics argue that ACP promotes the false notion of free college as an equalizer for lowincome students. For example, Tampio (2015) asserted that, rather than provide financial relief for deserving students, ACP presents as an oligarchic attempt to reward the pursuit of occupational skills so that students can become the trained personnel of multinational corporations.

Currently, some states are implementing their own interpretation of Obama's proposed legislations. Some states require students to decipher through the cumbersome criteria that qualifies one to be considered for free tuition depending on state reforms. Many students do not qualify for the grant because they are not recent high school graduates or do not have qualifying grade point averages (Palmadessa, 2017). And, those who do qualify still struggle to pay for expenses apart from tuition.

There are first dollar and last dollar state-managed Promise program models (The Association of Community College Trustees, n.d.). While first-dollar programs apply the Promise financial awards to a student's account before other financial aid is applied, state-managed last-dollar Promise programs require students to take all federal and state grants they are offered first, such as Pell Grants, and apply those to tuition. State derivatives of the national ACP model do not always account for the needs that students have outside of tuition costs. These needs often push students to accept loans to support their community college journey, even if grants and scholarships are earned and received. 


\section{Higher Education Politics \& Economics}

Further, community college students are less likely to take out loans to fund their education when compared to students at four-year institutions (Ma \& Baum, 2016). However, approximately $60 \%$ of students required aid in 2016. In the last three decades, since the Reagan era, the percentage of loans versus grants offered by the federal government has increased (Marklein, 2013; Palmadessa, 2017). And, compared to four-year university/college students, community college students are more likely to default on their loans, with $23 \%$ of public community college students having defaulted on loans entering repayment in 2011-2012 versus 9\% of four-year college students (Ma \& Baum, 2016). Not only does student debt conflict with the notion of community college's inherent affordability, there are also contradictions in the idea of applicability.

\section{APPLICABILITY}

Applicability is when a student attends a community college and can later apply what they learned while serving in their role as a part of the labor market. The concept of applicability tends to shift when it is quantified by its benefit to corporate entities instead of how it benefits the prospective job security of students and the sustainability of the community at-large. Applicability as a characteristic of the community college revolves around the idea that community colleges are institutions at the forefront of preparing America's workforce. Applicability, according to the Truman commission report, refers to the push to make curricula relevant to the needs of the society so that students leave community colleges prepared to work (Zook, 1947). At the time, the Cold War was burgeoning and industries in the technical and science fields were expanding. The country needed physicists and laborers who had both technical and a liberal arts background (Zook, 1947). The commission's reasoning was that the community college had the responsibility of building a curriculum that prepared students so that once they graduated, they would be available and trained to respond to the immediate issues the nation faced. The education students received was to be one that could be applied immediately in the field.

\section{Applicability as a Social Good}

Today, the characteristic of applicability is sustained as community colleges play a crucial role in the total system of workforce preparation. As students continue to enroll in community colleges to improve their self-sufficiency, the majors they are more apt to select are those with earning potential and, inevitably, fill the greatest need within corporate and government-run industries. Nursing, engineering, and business are among top choices outside of traditional vocational pathways available at more technical community colleges. Research indicates that occupational education and semi-professional graduates of community college (i.e., nurses and auto mechanics) are more apt to earn 15-30\% more than those who graduate high school and some who hold bachelor's degrees from four-year institutions (Dougherty et al., 2017). 
While community colleges continue this tradition of providing both liberal arts and vocational education, they also offer a wide variety of certificate programs and workforce development training. Workforce development training differs from vocational training as it is often offered as an opportunity to those who are already employed or seeking to transition into another career. Workforce development allows students to continue their training and education while also working. Oftentimes, providing training for a specific industry or, more specifically, a corporation or business, community colleges have forged an integral role in the field of workforce development. But, at what cost?

\section{Corporate Proximity Impacts State Funding}

The value of applicability and its impact on enterprise and community wellness informs state and federal funding of community colleges. Weerts (2014) found that individual state governments value colleges and universities based on their demonstrated commitment to the local and state community. This role has led state governments to be more apt to fund colleges and universities when these schools have demonstrated suitable levels of corporate partnership and a symbiotic relationship with companies that benefit corporate interests (Weerts, 2014).

Kromydas (2017) reasons that the "current policy focus on labor market driven policies in higher education have led to an ever-growing competition transforming this social institution to an ordinary marketplace, where attainment and degrees are currency that can be converted to a market labor value" (p. 1). Historical analysis suggests that the unique contributions of community colleges have been vulnerable to encroaching corporatist values since their inception. Giroux (2002) defined the infiltration of corporate ideals within the halls of educational institutions as neoliberalism. The trademark of neoliberalism is branding (Giroux, 2002) and schools and institutions have allowed corporations to leave their indelible mark for decades, such as through the naming of buildings after corporations, the sponsorship of signature events from job fairs, and educational conferences and homecoming festivities. Neoliberal policies foster a culture of individualism, labor exchange, and privatization, often within state and city-funded institutions (Giroux, 2002).

Between 1984 and 2004, Weerts (2014) gathered data that confirms that state schools receive higher levels of state funding when they have evidence demonstrating their benefit to the community. The word community is not particularly referring to community that includes the citizens of a neighborhood, the disenfranchised, or the neighboring K-12 schools, hospitals, and other governing agencies. Instead, the word is referring to corporations and the business industry. Weerts (2014) asserted that colleges and universities are more apt to receive generous state funding when they become known for their "engagement strategies as evidenced by high-profile partnerships with business" (p. 160). In short, corporate proximity garners higher levels of state funding, suggesting that industry-specific classroom instruction is not about knowledge building, but, in most ways, corporate indoctrination.

Giroux (2014) asserted that community colleges and universities increasingly strapped for money are driven by "vocational, military and economic considerations while increasingly removing academic knowledge production from democratic 


\section{Higher Education Politics \& Economics}

values and projects" (p. 138). In this context, the notion of applicability primarily applies to how the student is of value as human capital.

\section{PREDICTIONS}

Predicting where community colleges will be in the next twenty years regarding open access, affordability, and applicability relies on acknowledging today's trends and unavoidable truths. The predictions that follow are presented on the assumption that student learning, safety, and economic well-being should be the centering aspect of improvements over time. Also, while the overarching prediction is that corporations will continue to influence community college curriculum and state and federal funding for schools over the next twenty years, it is anticipated that a resistance to this total dominance will build in parallel form. Examples of this might include the voices and activism of faculty, thought leaders, and grassroots community-based individuals and organizations putting into praxis the theoretical ideologies and strategies of thinkers as diverse as Dewey to Giroux.

\section{Re-Thinking Remediation}

As a recap, my earlier assertion was that remedial courses diminish the actual practice of open access by community colleges. Because students are often placed in remedial courses because of placement test scores, the first step community colleges can take in re-thinking remediation begins in revamping the ways decisions are made when placing students in courses. Currently, less than $20 \%$ of public community colleges use artifacts such as high school transcripts, student co-curricular/extracurricular involvements, or teacher recommendations to assess college preparation. Instead they primarily use the Accuplacer test or similar placement tests (Fields \& Parsad, 2012; Mejia et al., 2016). Placement tests are still the greatest determinant of where a student is placed despite other factors within their academic file. However, some states are making headway in revamping how students are placed while also revamping the courses they are placed in.

The California Acceleration Project (CAP) uses an assets-based approach that recognizes that content in some remedial math courses does not provide outcomes that best serve all students nor teach skills necessary for all majors (Mejia et al., 2016). CAP works with 114 community colleges in California in an effort to replace traditional developmental courses by training college professors to transform their courses into ones where students of all levels can pass and learn math that is most applicable to their field of study. While the program has received backlash because it modifies math courses into more statistical and less algebraic courses, the program's results indicate that more than $82 \%$ of students pass the courses and persist through their academic programs (Maitre, 2014).

\section{The Ebbing Role of Remedial Courses}

I recommend the CAP project in California and programs like it as models for other states to redesign their programming for students who would be classified as 
remedial in math and reading. As funding continues to be predicated on graduation rates and corporate partnerships, community colleges will focus more on professional development for teaching faculty that will train faculty on ways to build stronger skills in teaching courses with learners who have multiple learning needs and respond to multi-disciplinary styles of learning. Kuh's theory of student engagement provides a theoretical framework to guide how to integrate different practices in a learning environment to achieve positive outcomes. Kuh's theory of student engagement broadens the theoretical framework already created by other theorists (e.g., Braxton's, Hirsch's, and McLendon's Theory of Student Persistence) and combines elements of the student involvement theory, introducing the need for learning to occur within high impact practices that make connections to real-world application (Walsh, 2015).

Gillett-Karam (2016) asserted that community colleges attract many students who are often marginalized and possess cultural capital that is not valued by society at large, resulting in previous experiences (or outside perceptions) of academic underachievement. Social inequities within American society at-large impact student potential at community colleges (Mellow, 2017). Most community college students struggle daily to balance student life, impacted by challenges brought on by job insecurity, childcare costs, and remediation needs to name a few (Mellow 2017; Pierce, 2016). While community college offers the promise of opportunity for marginalized students, a lack of services and support to help combat these life challenges continue to impact student persistence. State legislators could suggest that there are possible solutions to address the needs of community colleges serving students impacted by these challenges. These suggestions include requiring state schools to implement a case management model of advising and strengthening corporate accountability within privatized partnerships with community colleges.

\section{Institutional Solutions: A Case Management Model}

Community colleges continue to have "policies, practices and structures that are similar [to four-year institutions] with intended outcomes that are not [the same]" (Pusser \& Levin, 2009, p. 17). Most community colleges do not have an intake process that considers the student's individual needs although, community colleges serve more than $60 \%$ of college students who are placed in remediation courses (Pusser \& Levin, 2009) and are low-income and first-generation college students (Mellow, 2017). Instead of a case management system of advising that addresses the student's academic and personal needs and experiences impacting successful matriculation in one interaction with a college professional, most schools have separate departments that attend to different student needs.

Case management advising requires the ability to get to know students on a deeper level and follow up with regularly to monitor their progress and address barriers they may face. Therefore, advisors must be well-equipped to meet students' needs through reasonable case load numbers, enough time allotted to appointments, specialized knowledge and training about underprepared students, and diverse service delivery methods (email, websites, social media, etc.).

(Pierce, 2016, p.1) 


\section{Higher Education Politics \& Economics}

A state-mandated case management model would make student intake consistent regardless of what state community college a student attends and would allow for the easy transition of information inter-campus as well as across institutions. This type of system would also allow for data to be gathered and maintained to inform the creation of courses that are not remedial but college-level with appropriate supports in place to optimize student success. This state-mandated case management model would make schools more accountable for interactions with students from intake and throughout their matriculation, recording a tangible record of outreach to students and offered services and supports. It would also allow for informed funding decisions to be made as it becomes possible to see how much contact a school is making with a student and how that contact is maintained over the course of the student's enrollment history.

\section{Dual-Enrollment as Alternative to Remedial Courses}

As remedial courses will be phased out as courses are re-imagined and student support services are strengthened, the identity of open access praxis will broaden as access to an even younger demographic of student will become routine. Community colleges will continue to create bridge programs with high schools and incentivize community college as an option for younger students over the next twenty years. Early access to community college through dual-enrollment will be normalized by 2039. Already, dual-enrollment is impacting how students are prepared when they arrive to community college. Grubb et al. (2017) found that,

community college students who participated in dual enrollment were (a) $9 \%$ or nearly 3.4 times less likely to take remediation, (b) $26 \%$ or nearly 2.5 times more likely to graduate in 2 years, and (c) $28 \%$ or nearly 1.5 times more likely to graduate in 3 years. (p. 77)

What is necessary is that college personnel are equipped to adjust to the change. Ten years ago, Wilson (2009) reported that although dual-enrollment was gaining popularity, community college faculty and administrators were still unable to adjust to the needs of this population of students with the ease they have when interacting with students who have already graduated from high school. This was most likely due to unfamiliarity with the concept of dual-enrollment, lack of training, and lack of information-sharing across departments. That reality is shifting and, in twenty years, dual-enrollment will be a normalized enrollment practice.

\section{Dual-Enrollment's Impact on Local and State Policy}

College persistence is most often impacted by student engagement and college preparedness during the high school years (Kuh et al., 2008). In response to issues related to preparedness and persistence, states have adopted preventative practices by implementing dual-enrollment programs for students by transforming schools into middle college or early college high schools (Singleton, 2011). These schools are mainly formed with the singular goal of enrolling students who will graduate from high school with a high school diploma and college credits. In most cases, students 
earn an associate degree or other certification from a local community college. Today, dual-enrollment can be a controversial political issue because it is implemented inconsistently across the country as well as within some individual states (Pretlow \& Patteson, 2015).

I predict that community colleges based in the same state will become more in sync with each other regarding dual-enrollment policies as four-year institutions become inundated with an upsurge in requests for transferable credits from a larger number of high school students. McLendon, Hearn and Mokher (2009) found that states near each other influence the policy decisions regarding dual enrollment. This phenomenon was coined policy diffusion after review of the adoption pattern of different policies by states in proximity (McLendon, Hearn \&Mokher, 2009). State policy will improve internally among individual community colleges as associations and alliances crop up to advocate on behalf of dual-enrollment initiatives, requiring schools within states to improve their collaboration and sync their practices. One example is the College in High School Alliance. This alliance "supports dualenrollment programs for high-school students to earn college credit, [and] spent $\$ 80,000$ on lobbying in 2017, the alliance's first year in operation" (Korn \& Hackman, 2018, para. 14). If almost all public high schools are not designed as early access schools, there will be a dual-enrollment option for students to begin taking college courses by or before their junior year of college. This will reconcile many issues regarding affordability as students will have less schooling to pay for if they start community college earlier.

\section{Affordability}

In the next twenty years, community college affordability will continue to be an issue. Although $64 \%$ of community college students are Pell grant recipients (Ma \& Baum, 2016), some students still take out loans to support themselves (McKinney et al., 2015), with loans serving as an "adjunct to welfare" (Cohen et al., 2014, p. 163). While the rhetoric around the American College Promise initiatives idealizes community college affordability as a means to creating meaningful gains in human capital and as a benefit to local economy (assuming that affordability equals higher rates of entry and graduation), the subsequent state derivatives of the ACP initiative are more geared toward recent high school graduates. While I predict that the age range will diversify among the community college population as dual-enrollment becomes normalized at the same time as our population and more senior citizens will opt to take courses, community college costs will continue to be a struggle for students who works at least part-time and care for a family as socio-economic gaps widen and the middle class continues to shrink exponentially.

Community colleges will redesign how financial aid operates, relying on apprenticeships to address both issues of affordability and applicability. Apprenticeships are not a new form of job training and have existed long before the Americas were colonized. What is new is the way the federal government and corporate sector have aligned to create apprenticeships that pay for student education as students train within the field. 


\section{Higher Education Politics \& Economics}

Between 1939 and 1947, US citizens were unlikely to choose the economic burden of financing an education because a war was taking place and tuition increased. This lag in enrollment and credentialing warranted concern as The Truman commission recognized and the report emphasized the deleterious effect this had on corporate industry (Zook, 1947). As history repeats, with the US government proclaiming the need to rebuild human capital in particular industries, the U.S. Department of Labor announced in 2016 that they had bestowed "\$175 million in grant opportunities that would fund apprenticeship programs in high-growth industries such as health care, advanced manufacturing, and information technology (O'Banion, 2019, p. 221). The intended beneficiaries of such an arrangement are corporations receiving reduced cost labor and students receiving paid training while building new skills. The possible consequence of such an arrangement will become more commonplace within twenty years and, if left to expand without pushback, will be the demise of a diverse liberal arts education within community colleges as certain majors will no longer be offered to the total erosion of general education requirements.

Ultimately, history confirms that affordability of community colleges has always been predicated on the potential human capital created once government grants and loans are available to students (Cohen et al., 2014; Palmadessa, 2017). The human capital created almost always serves in corporate capacity. Apprenticeships will further serve this agenda.

\section{Applicability}

John Dewey said in 1916 that "vocational education is often narrowly conceived as mere occupational training and cautioned that educational institutions could be mere appendages to business concerns or whims of the labor market" (Pusser \& Levin, 2009). Workforce applicability as a characteristic of community colleges is a polarizing issue. Critics like Giroux (2002) and Tampio (2015) believed applicability can manifest as neoliberal policy that fosters a culture of individualism, labor exchange, and privatization, often within state and city-funded institutions. Yet, scholars like Berdahl (2014) assessed applicability as a contribution to the health of America's enterprise economy and a beneficial and stable force in America's colleges and universities. While the reality is that industry drives what is offered, and oftentimes how schools are funded, corporate influence poses ethical dilemmas that potentially compromise the integrity of public community colleges. Albeit, I predict that corporate partnerships will only broaden in the years to come as state funding shrinks and schools become even more reliant on the money corporate branding garners.

There is a heavy presence of corporate influence within the curriculum and policy initiatives driving higher education (Giroux, 2002). As Holmes and Lindsay (2018) asserted, "students are effectively reduced to economic income units, and strategic planning in the neoliberal university occurs around projected income opportunities rather than social need, scholarly agendas, or the expertise and interests of its academic staff' (p. 7). This will only get worse as the critics of this system become outnumbered and a growing class of corporatists masked as academics, educators, 
and champions of education are incentivized to dismantle protections that uphold academic freedoms.

Corporations benefit from free and reduced cost labor at the expense of institutions and student well-being and there are reasonable expectations that should be required before relationships are established. Community college partnerships with corporations need to be beneficial to the students first and foremost in ways that benefit academic success and student well-being. States should only offer tax credits and benefits to corporations that guarantee funding of educational services and supports aligned with work opportunities for community college students. Additionally, if corporate sponsorships of services and supports for students in the community college were formalized in ways that not only supported student matriculation, but also student job attainment, then the earlier-mentioned issues that many community college students face regarding affordability - particularly those who are working full-time, receive low income, and are heads of their householdswould be abated and community college success outcomes might improve.

A solution lies in the strategic movement of faculty, administrators, and intellectuals armed with an understanding of historical precedent and a dedication to the doctrines that the general public understands higher education to represent. Together, this group must prepare to serve in political capacities to preserve noncommodified public spheres and confront the corporatization of education through learning and learner-centered initiatives that demonstrate value and benefit to both students and industry without the sacrifice of culture, critical thought, constitutional freedoms, and human dignity. In tandem with the re-imagining of remedial education, adoption of dual-enrollment models, and broadening of programs to help students afford their education, community colleges can best serve their multi-function purpose. This solution is dependent more on the moral compass of decision-makers who impact funding more so than considering or engaging in rhetorical suggestion that alternative methods have not been applied in the best interest of students because budgets restrict the prioritization of students. Many of these predictions and suggestions are moored to the belief that change for better begins with a paradigmshifting mindset that puts people over profit.

\section{CONCLUSION}

Community colleges have contributed to the American system of higher education by championing the doctrines of open access, affordability, and applicability. The state of remedial education, student debt, and corporate partnerships negatively impacts the actual implementation of these ideals. In the coming years, we will notice community colleges broadening their multi-functional platform as the demographic of their student populations change and states continue to require public community colleges to partner with corporations in order to receive state funding.

Younger students will increase in number through dual-enrollment and other early access options, influencing the need for community college to build skills to serve this group and financial aid opportunities for the average community college student to expand. While popular policies have sprouted for students who are recent high school grads, opportunities for older students are still necessary. 


\section{Higher Education Politics \& Economics}

We will also find community colleges utilizing apprenticeships as ways to offer students opportunities for on-the-job training and financial assistance while corporate partners will benefit from low paid workers who are still enrolled in school. While the ever-expanding corporate presence will remain, schools will be challenged with the task of centering learning and ensuring that the ideals of open access, affordability, and applicability do not fall by the wayside. In closing, a school's success will depend on their understanding of precedent and a keen appraisal of how they are creating pathways versus erecting barriers for students.

\section{REFERENCES}

Allen, J. P. \& Turner, E. (1989). The most ethnically diverse urban places in the United States. Urban Geography, 10(6), 523-539.

Bailey, T. R., Jaggars, S. S., \& Jenkins, D. (2015). Redesigning America's community colleges. Harvard University Press.

Baum, S., Ma, J., Bell, D. W., \& Elliott, D. C. (2014). Trends in college pricing 2014. College Board. https://files.eric.ed.gov/fulltext/ED572551.pdf

Berdahl, R. (2014). Thoughts on the history of university systems in the US. Center for Studies in Higher Education, 1-5. http://escholarship.org/uc/item/8mv7h2wx

Berube, M. R. (1991). American presidents and education. Greenwood Press.

Boggs, G. R., \& McPhail, C. J. (2016). Practical leadership in community colleges. Jossey-Bass.

Borstelmann, T. (1999). Jim crow's coming out: Race relations and American foreign policy in the Truman years. Presidential Studies Quarterly, 29(3), 549-569.

Cohen, A. M., Brawer, F. B., \& Kisker, C. B. (2014). The American community college (6th ed.). Jossey-Bass.

Dougherty, K. J., Lahr, H., \& Morest, V. S. (2017). Reforming the American community college: Promising changes and their challenges (CCRC Working Paper No. 98). Teachers College, Columbia University.

https://ccrc.tc.columbia.edu/media/k2/attachments/reforming-americancommunity-college-promising-changes-challenges.pdf

Fields, R., \& Parsad, B. (2012). Tests and cut scores used for student placement in postsecondary education: Fall 2011. National Assessment Governing Board. https://files.eric.ed.gov/fulltext/ED539918.pdf

Gillett-Karam, R. (2016). Student affairs: Moving from theories and theorists to practice and practitioners. New Directions for Community Colleges, 2016(174), $85-91$.

Giroux, H. A. (2002). Neoliberalism, corporate culture, and the promise of higher education: The university as a democratic public sphere. Harvard Educational Review, 72(4), 425-463. Retrieved from https://search-proquest com.proxyms.researchport.umd.edu/docview/212279730?accountid=12557

Giroux, H. A. (2014). Neoliberalism's war on higher education. Haymarket Books.

Graham, H. D. (2011). The uncertain triumph: Federal education policy in the Kennedy and Johnson years. UNC Press Books. 
Great Schools Partnership. (2014). Access. The Glossary of Education Reform. http://edglossary.org/access

Grubb, J. M., Scott, P. H., \& Good, D. W. (2017). The answer is yes. Community College Review, 45(2), 79-98.

Hansen, W. L., \& Stampen, J. O. (1987). Economics and financing of higher education: The tension between quality and equity. In P. G. Altbach, \& R. O. Berdahl (Eds.), Higher Education in American Society (2nd ed., pp. 101-125). Prometheus Press.

Holmes, C., \& Lindsay, D. (2018). "Do You Want Fries With That?": The McDonaldization of university education-Some critical reflections on nursing higher education. SAGE Open, 8(3). https://doi.org/10.1177/2158244018787229

Hutcheson, P. A. (2007). The Truman Commission's vision of the future. Thought \& Action, (2007)107-115.

Korn, M., \& Hackman, M. (2018, Feb 23). Education bill brings out some unusual lobbying suspects. Wall Street Journal.https://www.wsj.com/articles/educationbill-brings-out-some-unusual-lobbying-suspects-1519381801

Krantz, L. (2015, July 3). For many, remedial math not a solution. The Boston Globe. https://www.bostonglobe.com/metro/2015/07/03/state-tackles-remedial-mathneeds-colleges/3pFZYtPhJJ4HZrGneP0UJI/story.html

Kromydas, T. (2017, October 13). Rethinking higher education and its relationship with social inequalities: Past knowledge, present state and future potential. Palgrave Communications, 3(1).

Kuh, G. D. (2009). What student affairs professionals need to know about student engagement. Journal of College Student Development, 50(6), 683-706.

Kuh, G. D., Cruce, T. M., Shoup, R., \& Kinzie, J. (2008). Unmasking the effects of student engagement on first-year college grades and persistence. Journal of Higher Education, 79(5), 540-563.

Ma, J., \& Baum, S. (2016, April). Trends in community colleges: Enrollment, prices, student debt, and completion. College Board Research.

https://research.collegeboard.org/pdf/trends-community-colleges-researchbrief.pdf

Maitre, M. (2014, November 11). Reworking remedial education. EdSource. https://edsource.org/2014/reworking-remedial-education/69786

Marklein, M. (2013, August 20). Students get financial aid at highest rates since WWII. USA Today.

http://www.usatoday.com/story/news/nation/2013/08/20/student-aid--amountsincreasing/2677237/

McLendon, M., Hearn, J, \& Mokher, C. (2009). Partisans, professionals, and power: The role of political factors in state higher education funding. The Journal of Higher Education, 80(6), 687-713.

McKinney, L., Mukherjee, M., Wade, J., Shefman, P., \& Breed, R. (2015). Community college students' assessments of the costs and benefits of borrowing to finance higher education. Community College Review, 43(4), 329-354. 


\section{Higher Education Politics \& Economics}

Mejia, M. C., Rodriguez, O., \& Johnson, H. (2016, November). Preparing students for success in California's community colleges. Public Policy Institute of California. http://www.ppic.org/content/pubs/report/R_1116MMR.pdf

Mellow, G. O. (2017, August 28). The biggest misconception about today's college students. The New York Times. https://www.nytimes.com/2017/08/28/opinion/community-collegemisconception.html?mcubz $=1 \& \_\mathrm{r}=0$

Nevarez, C., \& Wood, J. L. (2010). Community college leadership and administration: Theory, practice, and change. Lang.

O'Banion, T. U. (2019). A brief history of workforce education in community colleges. Community College Journal of Research and Practice, 43(3), 216-223.

Palmadessa, A. L. (2017). America's College Promise: Situating President Obama's initiative in the history of federal higher education aid and access policy. Community College Review, 45(1), 52-70.

Pierce, L. (2016, December). The case for a case management approach in advising academically underprepared students. Academic Advising Today, 39(4).

Pretlow, J., \& Patteson, J. (2015). Operating dual enrollment in different policy environments: An examination of two states. New Direction for Community Colleges, 2015(169), 21-29.

Pusser, B., \& Levin, J. (2009, December 8). Re-imagining community colleges in the 21 st century. Center for American Progress.

https:/www.americanprogress.org/issues/economy/reports/2009/12/08/7083/reimagining-community-colleges-in-the-21st-century/

Shaw, K. M., Valadez, J. R., \& Rhoads, R. A. (Eds.). (1999). Community colleges as cultural texts: Qualitative explorations of organizational and student culture. SUNY Press.

Singleton, H. (2011). An early/middle college high school case study: How graduates perceive their experiences as contributing to their academic success and college preparedness (Doctoral Dissertation). Available from ProQuest Central (Order No. 3471663).

Smith Morest, V. (2013). From access to opportunity: The evolving social roles of community colleges. The American Sociologist, 44(4), 319-328.

St. Rose, A., \& Hill, C. (2013). Women in community colleges: Access to success. American Association of University Women. https://www.aauw.org/files/2013/05/women-in-community-colleges.pdf

Tampio, N. (2015). There is no such thing as free community college. Aljazeera America. http://america.aljazeera.com/opinions/2015/8/there-is-no-such-thingas-free-community-college.html

The Association of Community College Trustees. First dollar vs. last dollar promise models. (n.d.). https://www.acct.org/page/first-dollar-vs-last-dollar-promisemodels

Thelin, J. R. (2011). A history of American higher education. Johns Hopkins University Press. 
Walsh, R. M. (2015). Active and collaborative learning at a community college in a mid-Atlantic state (Doctoral Dissertation). Available from ProQuest Dissertations and Theses database (No. 10076275).

Weerts, D. J. (2014). State funding and the engaged university: Understanding community engagement and state appropriations for higher education. Review of Higher Education, 38(1), 133-169.

Wilson, M. E. (2009). Struggle and success: The experiences of urban high school seniors participating in a dual enrollment program (Doctoral Dissertation). Available from ProQuest Central (No. 3354348).

Zook, G. (1947). Higher education for democracy: A report of the president's commission on higher education. President's Commission on Higher Education.https://www.aacu.org/sites/default/files/files/LEAP/he_for_democra cy.pdf

KHADIJAH Z. ALI-COLEMAN, EdD, is a recent graduate within the Department of Advanced Leadership \& Policy Studies at Morgan State University. Her research focuses on community college high impact practices, dual-enrollment, and college preparedness. Email khali1@morgan.edu 